\title{
Fluoração Seletiva por Catálise Fotorredutora Usando Sais Arilssulfónio e LEDs
}

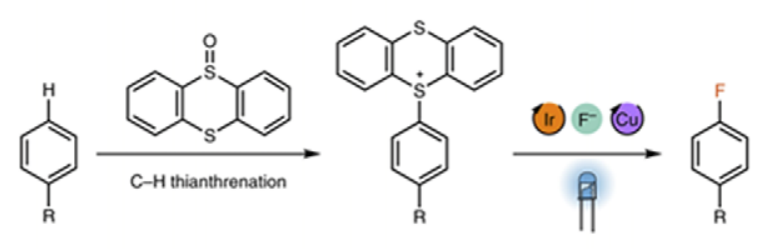

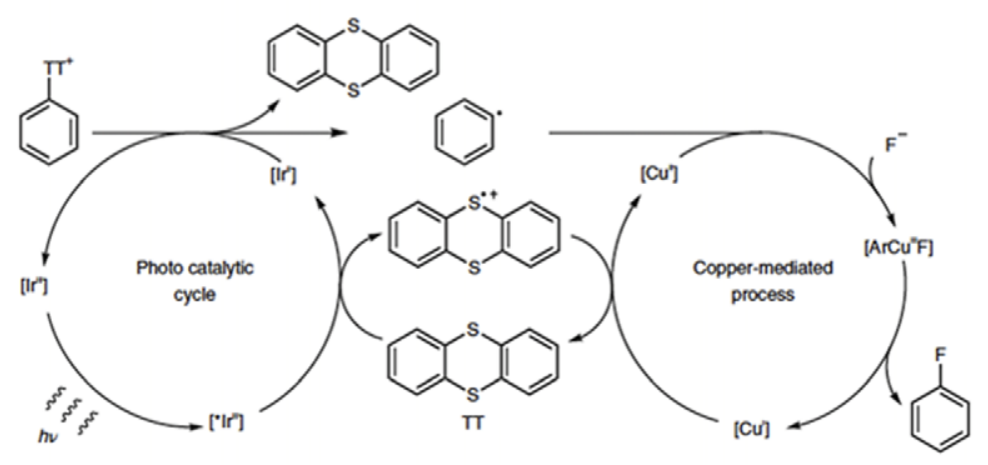

A fotocatálise, em especial a catálise fotorredutora usando metais de transição, permite a realização de transformações químicas que não são facilmente acessíveis através da catálise redox convencional. A fluoração nucleofílica catalisada por paládio está bastante desenvolvida, contudo a presença de grupos funcionais contendo protões lábeis e outros grupos que possam interferir no acoplamento cruzado (ex. halogenetos) são ainda um desafio neste tipo de metodologia; além disso, materiais de partida, tais como halogenetos de arilo, para uso em funcionalizações seletivas numa fase avançada da síntese geralmente não estão acessíveis.
Investigadores alemães e belgas desenvolveram um novo sistema fotocatalítico, baseado num ciclo catalítico de irídio e cobre, para a realização de fluorações seletivas recorrendo a sais de arilssulfónio $\left(E_{1 / 2}{ }^{*}=-1,5 \mathrm{~V}\right.$ vs. SCE $)$ e díodos emissores de luz (LEDs) na região do azul. 0 método foi aplicado com sucesso à síntese de diversos fármacos.

\section{Vasco Bonifácio}

vasco.bonifacio@tecnico.ulisboa.pt

\section{Fontes}

J. Li, Ju. Chen, R. Sang, W.-S. Ham, M.B. Plutschack, F. Berger, S. 